\title{
The Dispersed Pancreas: Transplantation without Islet Purification in Totally Pancreatectomized Dogs
}

\author{
G. J. Kretschmer ${ }^{1}$, D. E. R. Sutherland, A. J. Matas, M. W. Steffes, and J.S. Najarian \\ Departments of Surgery and Laboratory Medicine and Pathology, University of Minnesota, Minneapolis, Minnesota, USA
}

\begin{abstract}
Summary. Forty-eight mongrel dogs were made diabetic by total pancreatectomy. Fifteen untreated pancreatectomized animals survived for a mean of $7 \pm 1$ (SEM) days. Thirty-three dogs were divided into five groups and received autotransplants to the spleen of pancreatic fragments dispersed by collagenase digestion for $0,10,15,20$ or 25 minutes. Animals transplanted with tissue digested for 0 minutes or for 10 minutes remained hyperglycaemic (mean survival $22 \pm 12$ days and $28 \pm 9$ days). Normoglycaemia occurred in all but one of 21 dogs transplanted with tissue digested for 15-25 minutes. Two weeks after transplantation tolbutamide and glucose tolerance curves in the group receiving tissue digested for 20 minutes most closely resembled those of normal animals. Glucose tolerance test $\mathrm{K}$ values in dogs receiving tissue digested for 15,20 and 25 minutes were $1.20 \pm 0.19$ percent, $1.60 \pm 0.25$ percent and $0.78 \pm 0.08$ percent, respectively. The $\mathrm{K}$ values of the transplanted animals were significantly different from the $\mathrm{K}$ value of $0.35 \pm 0.05$ percent in the apancreatic control dogs $(\mathrm{p}<0.001)$. The mean $\mathrm{K}$ value of the dogs transplanted with tissue digested for 20 minutes was significantly better than the value in the dogs transplanted with tissue digested for 25 minutes $(\mathrm{p}<0.02)$, but was significantly less than the $K$ value $(3.30 \pm 0.27$ percent $)$ obtained in 22 normal control dogs $(\mathrm{p}<0.005)$. Hyperglycaemia recurred immediately following splenectomy in 12 normoglycaemic dogs 10 weeks after transplantation and all animals died. The remaining normoglycaemic transplanted dogs survived for at least six months. Histological examination of spleens from the transplanted animals showed the presence of islet and exocrine tissue within the sple-
\end{abstract}

1 Current address: G. J. Kretschmer, M. D., I. Surgical University Clinic, Alser Straße 4, A-1097 Vienna, Austria nic pulp with no apparent destructive effect on surrounding splenic parenchyma.

Key words: Pancreatectomy, experimental diabetes in dogs, collagenase digestion, transplantation, spleen.

Many investigators have reported that experimental diabetes in rodents can be ameliorated by autotransplantation [1-8] or allotransplantation [9-14] of pancreatic islet tissue. Only sporadic reports of islet transplantation in larger animals, such as the pig [15] and monkey [16], have appeared; these attempts have been less successful, largely because the techniques of islet preparation used for rats [17] are not easily applied to larger species [18]. Low islet yield is a major obstacle for clinical transplantation.

One approach to the problem of recovering a sufficient amount of islet tissue is to transplant pancreatic fragments without separation of exocrine and endocrine components. The feasibility of this approach is suggested by the following evidence: (a) dispersed neonatal rat pancreatic tissue can be successfully transplanted without specific islet isolation to diabetic rats $[19,20]$; (b) adult dog pancreatic fragments, depleted of exocrine enzymes by short term tissue culture, can prolong survival and reduce the incidence of hyperglycaemia when autotransplanted via the portal vein to partially pancreatectomized dogs treated with streptozotocin [21]; and (c) Mirkovitch and Campiche successfully implanted fresh pancreatic fragments into the spleen of diabetic dogs [22].

Principal questions regarding transplantation of pancreatic fragments are: (a) how can the pancreatic 
tissue be most effectively dispersed; (b) will islets transplanted in association with exocrine tissue and enzymes function as a free graft; and (c) will the exocrine tissue and enzymes be injurious to the host? In this report, we describe a method of tissue preparation and the results obtained with autotransplantation of fresh pancreatic fragments into the spleen of totally pancreatectomized dogs.

\section{Materials and Methods}

\section{Animals}

Twenty-two dogs did not undergo surgery and constituted the normal control group (NC) for establishment of normal fasting plasma glucose levels and normal intravenous glucose and tolbutamide tolerance curves.

Forty-eight dogs were subjected to total pancreatectomy. Fifteen pancreatectomized dogs received no treatment and constituted the apancreatic control group (APC). The remaining 33 pancreatectomized dogs were randomly placed in five experimental groups and received autotransplants of pancreatic tissue into the spleen. Ringers' lactate was administered intravenously for the first three postoperative days to all pancreatectomized animals. Thereafter they were maintained on water ad libitum, standard kennel diet, and commercial pancreatic extract (Viokase, Viobin Corporation) in an attempt to compensate for exocrine enzyme deficiency.

\section{Technique of Pancreatic Tissue Preparation and Transplantation in Experimental Groups}

The main pancreatic duct was cannulated immediately before pancreatectomy and the pancreas was disrupted with retrograde injection of $30-50 \mathrm{ml}$ cold $\left(4^{\circ} \mathrm{C}\right)$ Hanks' solution containing $8.25 \mathrm{mg} / 100 \mathrm{ml}$ of aprotinin (Trasylol, FBA Pharmaceuticals). Following removal, the entire pancreas was minced in a mechanical tissue chopper [21] and digested at $37^{\circ}$ in a shaking water bath with 600 units of collagenase (Worthington, Type IV) $/ \mathrm{ml}$ of settled tissue for varying amounts of time $(0,10,15,20$ or 25 minutes. The mean ( \pm SEM) wet weight of pancreas contained in $1 \mathrm{ml}$ of chopped tissue was 0.41 $\pm 0.01 \mathrm{gm}$. The five experimental groups were based on the duration of collagenase digestion. The number of dogs in each experimental group was 5 , $7,8,7$, and 6 respectively.

Islet cell and exocrine enzyme attrition during the tissue preparation was estimated by determining the tissue insulin and amylase content of aliquots taken after each step in the process. These measurements were made under the assumption that tissue amylase content and insulin content are proportional to pancreatic beta cell and exocrine tissue mass, respectively [23]. Insulin was measured by the double-antibody radioimmunoassay technique of Morgan and Lazarow [24], using porcine insulin standards (gifts of the Eli Lilly Co.). Amylase was measured by the technique of Jamieson et al [25] using hog pancreatic alpha amylase (Sigma Chemicals, 900 units $/ \mathrm{mg}$ ) as the standard.

The entire quantity of pancreatic tissue remaining after collagenase digestion was immediately transplanted to the spleen of each autograft recipient. The splenic and short gastric vessels were occluded with vascular clamps, the splenic capsule was punctured, and an angiographic catheter (internal diameter $2 \mathrm{~mm}$ ) with wire guide was directed into the splenic pulp from the upper to the lower pole. The wire was removed and a syringe containing the dispersed pancreatic tissue $(20-40 \mathrm{ml})$ was connected to the catheter. The pancreatic tissue was evenly distributed throughout the splenic pulp as the catheter was gradually withdrawn. Haemostasis was obtained by suturing a piece of gelatin sponge (Gelfoam, Upjohn Company) over the site of capsular puncture and splenic circulation was re-established by removing the vascular clamps.

\section{Survival and Metabolic Studies}

All results are given as mean \pm SEM. Significance of differences between groups ( $\mathrm{p}$ values) were calculated using Student's t-test for small numbers.

Fasting plasma glucose determinations were made in APC and experimental dogs before and immediately after pancreatectomy, daily for two weeks after operation, and weekly thereafter. Plasma glucose levels were measured in duplicate by the glucose oxidase method [26] using a Beckman autoanalyzer. An additional glucose determination was made in the experimental dogs 4 hours after transplantation. Normoglycaemia was defined as a plasma glucose of less than $150 \mathrm{mg} / 100 \mathrm{ml}$ after a 12 hours fast.

Eight of the APC dogs who were alive at 5 days after pancreatectomy had intravenous tolbutamide tolerance tests performed and 6 of the APC dogs who were alive at 7 days had intravenous glucose tolerance tests performed. The twenty-one of the thirty-three autotransplant recipients that became normoglycaemic were subjected to glucose tolerance tests at 14 days and tolbutamide tolerance tests at 16 days after transplantation. For glucose tolerance 


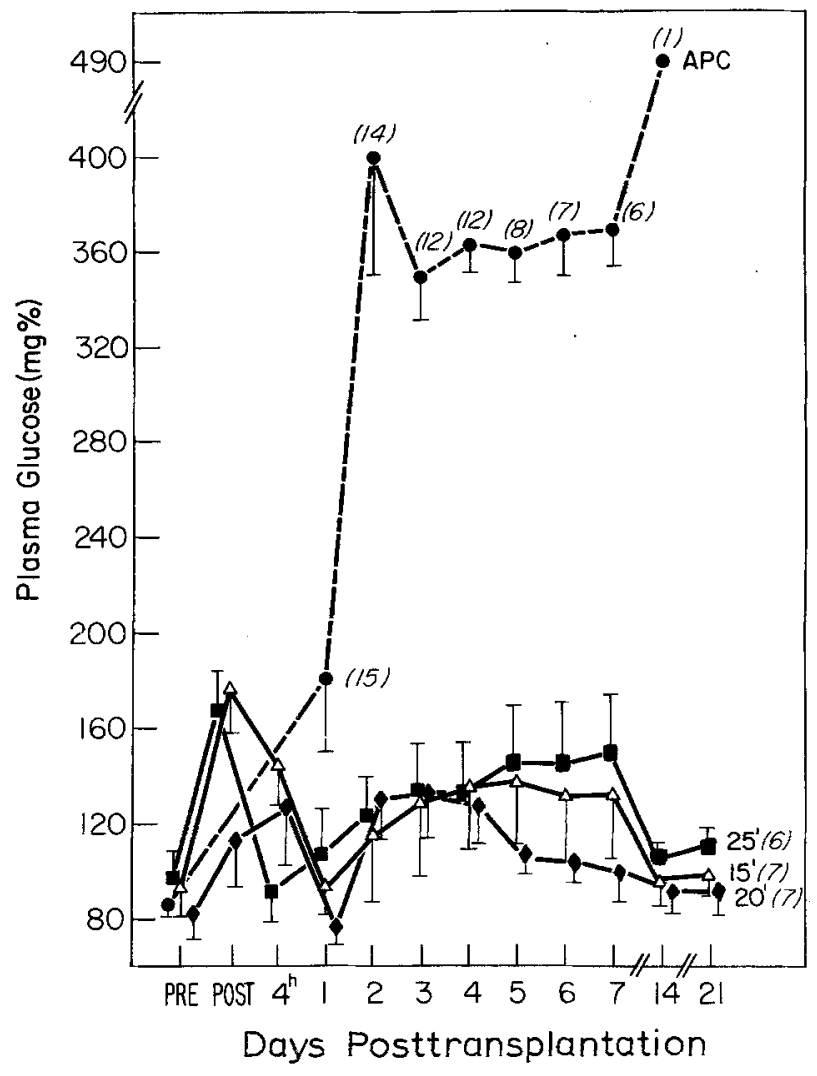

Fig. 1. Serial plasma glucose levels (mean \pm SEM) in apancreatic dogs (APC) and in pancreatectomized dogs receiving pancreatic tissue digested for 15,20 or 25 minutes. Numbers in parentheses refer to number of animals tested

tests, 0.5 gm of glucose $/ \mathrm{kg}$ body weight was administered, and for tolbutamide tolerance tests $50 \mathrm{mg}$ of tolbutamide was administered to each dog. Blood samples were collected before injection ( 0 minutes) and at $10,20,30,40,60,90$ and 120 minutes after injection. $\mathrm{K}$ values (percent decline of plasma glucose concentrations per minute) during glucose tolerance tests were calculated from the 10,20 , and 30 minute postinjection plasma glucose values, according to the method of Moorhouse et al. [27]. Plasma insulin levels were measured by the method of Morgan and Lazarow [24].

Ten weeks after transplantation, splenectomies were performed in four dogs from each of the experimental groups receiving tissue digested for 15,20 , and 25 minutes. Plasma glucose levels were measured immediately and daily until death.

Spleen specimens, obtained from the splenectomized dogs and from the experimental dogs that died during the study, were fixed in 5 percent formalin or Bouin's solution, and routinely processed for histological examination. Formalin fixed specimens were stained with haematoxylin and eosin $(\mathrm{H}$

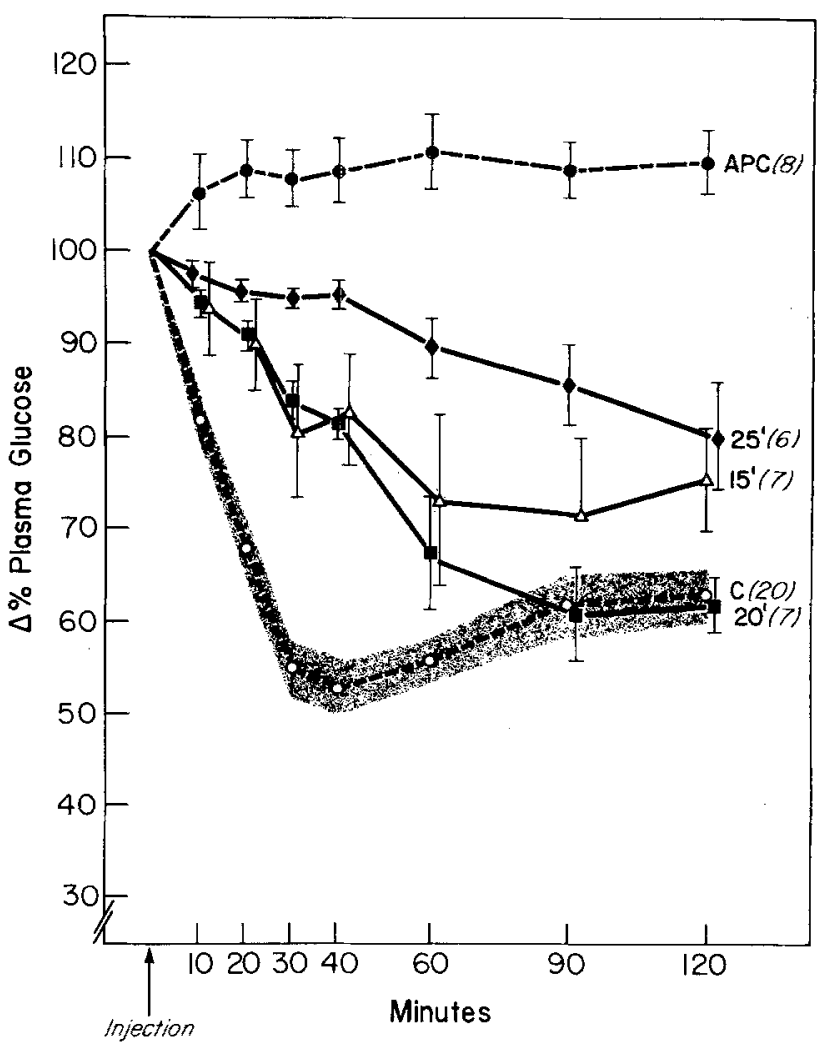

Fig. 2. Intravenous tolbutamide tolerance test curves in normal dogs (C), apancreatic dogs (APC) and pancreatectomized dogs receiving pancreatic tissue digested for 15,20 or 25 minutes. Values are expressed as mean \pm SEM. Numbers in parentheses refer to number of animals tested

\& E) or with phosphotungstic acid-haematoxylin (PTAH) [28, 29]. Bouin's fixed specimens were stained with aldehyde fuchsin [30]. Spleen sections were examined for the presence of exocrine tissue (zymogen granules within acinar cells stained purple with PTAH) and islets (beta cells stained purple with aldehyde fuchsin), and for evidence of splenic pulp destruction. A cyst encountered in one spleen was aspirated and the fluid analyzed for amylase content.

\section{Results}

\section{Survival and Metabolic Studies}

Apancreatic Control Dogs. All 15 APC dogs died within 15 days (mean survival $7 \pm 1$ days). Fasting plasma glucose levels rose immediately after pancreatectomy and remained elevated (> $300 \mathrm{mg}$ ) $100 \mathrm{ml}$ ) until death (Fig. 1). Plasma glucose concentrations during tolbutamide tolerance tests (Fig. 2) and glucose tolerance tests (Fig. 3) performed on the 


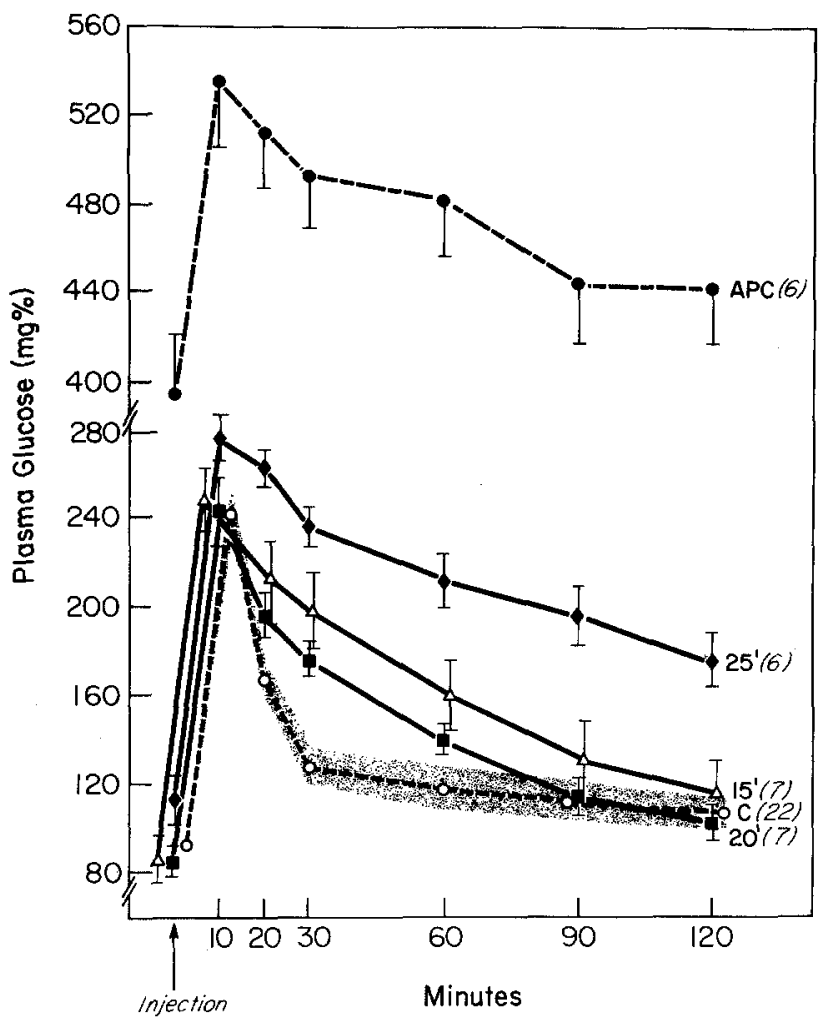

Fig. 3. Intravenous glucose tolerance test curves in normal dogs (C), apancreatic dogs (APC), and pancreatectomized dogs receiving pancreatic tissue digested for 15,20 , or 25 minutes. Values are expressed as mean \pm SEM. Numbers in parentheses refer to number of animals tested

Table 1. Results of transplantation in pancreatectomized dogs as function of duration collagenase digestion of pancreatic fragments

\begin{tabular}{lll}
\hline $\begin{array}{l}\text { Minutes } \\
\text { Collagenase } \\
\text { Digestion }\end{array}$ & $\begin{array}{l}\text { Number } \\
\text { Animals } \\
\text { Transplanted }\end{array}$ & $\begin{array}{l}\text { Number } \\
\text { Becoming } \\
\text { Normoglycaemic }\end{array}$ \\
\hline 0 & 5 & 0 \\
10 & 7 & 1 \\
15 & 8 & 7 \\
20 & 7 & 7 \\
25 & 6 & 6 \\
\hline
\end{tabular}

dogs that survived at least 5 days confirmed the functional apancreatic state. Plasma insulin before and after stimulation with tolbutamide and glucose were below the lowest level of the insulin assay sensitivity $(<4 \mu \mathrm{U} / \mathrm{ml})$. No dog was found to have residual pancreatic fragments or ectopic pancreatic tissue at autopsy.

Experimental Dogs. Table 1 shows the incidence of normoglycaemia in pancreatectomized recipients of pancreatic tissue that had been subjected to varying periods of collagenase digestion. None of the five transplant attempts with undigested tissue was successful, all dogs remaining hyperglycaemic, dying between the fourth and fifty-sixth day (mean survival $22 \pm 12$ days).

One of seven recipients of tissue digested for 10 minutes became normoglycaemic and survived the entire observation period ( 6 months). One other dog in this group died on the first postoperative day as a result of a technical complication (splenic rupture) associated with improper distribution of a large volume of tissue. The hyperglycaemic dogs of the 10 minute experimental group lived for five to fifty-three days (mean survival $28 \pm 9$ days).

Twenty of the 21 dogs receiving grafts of pancreatic tissue digested for 15,20 , or 25 minutes became normoglycaemic. The fasting plasma glucose levels of these three groups of animals had a similar pattern, and consisted of two peaks (Fig. 1). The first peak occurred during the operative procedure, and corresponded to the apancreatic phase. The second peak lasted for several days, but varied with the length of collagenase digestion. The second peak was of the shortest duration in the dogs receiving tissue digested for 20 minutes. Results of intravenous tolbutamide and glucose tolerance tests (Fig. 2 and 3) further suggest that glucose metabolism was best regulated in the 20 minute experimental group.

Quantitative differences between the successful groups and the normal and apancreatic control dogs are shown in Table 2 . The $\mathrm{K}$ value of the 20 minute group was increased significantly over that of the 25 minute group $(p<0.02)$ but not over that of the 15 minute group $(p>0.2)$. Although the $K$ values of the 15,20 , and 25 minute groups were significantly less than that of the normal control dogs ( $p$ $<0.005)$, the values are clearly improved over those for the APC dogs $(p<0.001)$.

Mean fasting and peak plasma insulin levels during tolbutamide and glucose tolerance tests in the successfully transplanted dogs were $6 \pm 1,10$ \pm 2 and $7 \pm 1 \mu \mathrm{U} / \mathrm{ml}$, respectively. In contrast, mean fasting and peak plasma insulin levels during tolbutamide and glucose tolerance tests in the normal control dogs were $6 \pm 1,34 \pm 16$ and 39 $\pm 12 \mu \mathrm{U} / \mathrm{ml}$, respectively.

All pancreatectomized dogs lost weight, including transplanted animals in which the diabetic state was ameliorated. We were unable to distinguish between weight loss due to pancreatic endocrine or exocrine deficiency, but all pancreatectomized dogs had loose and foul stools suggesting that administration of Viokase was inadequate therapy for pancreatic exocrine deficiency.

In the one dog in the 15 minute collagenase digestion group who remained hyperglycaemic, the 


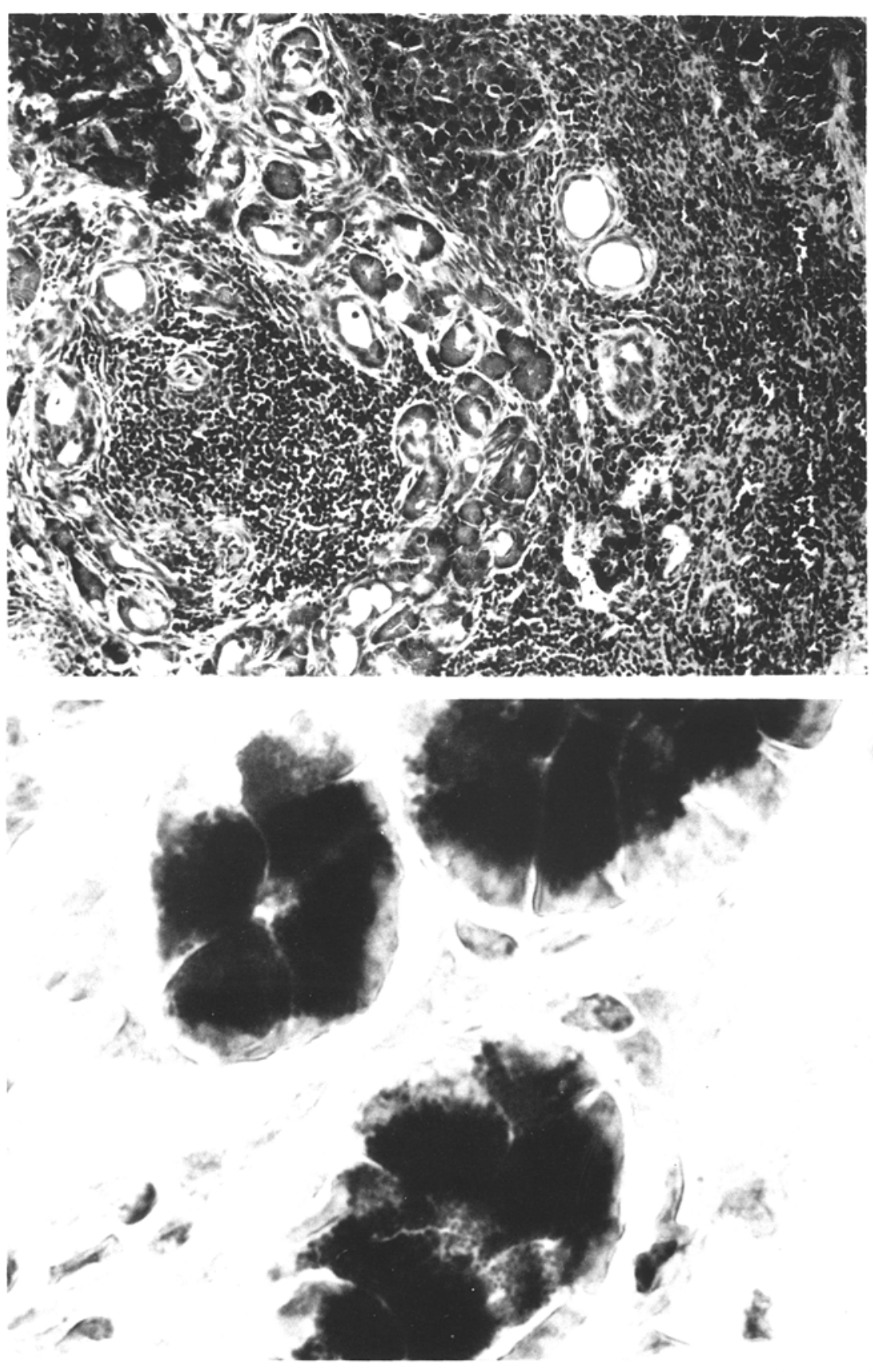

Fig. 4. Spleen section from pancreatectomized dog four weeks after autotransplantation of pancreatic fragments. The transplanted tissue, with a characteristic glandular appearance, is distributed thoughout the splenic pulp (H \& E X 142)
Fig. 5. Spleen section from pancreatectomized dog four weeks after autotransplantation of pancreatic fragments showing well formed acini containing zymogen granules (PTAH X 1.425) dispersed pancreas was improperly implanted, resulting in uneven distribution of the tissue within the spleen. This dog survived 33 days and at autopsy a cyst was encountered in the lower pole of the spleen. The amylase level within the cyst was equivalent to the serum amylase level of normal dogs.

Splenectomy. The hyperglycaemic state immediately recurred in all 12 experimental dogs that underwent splenectomy. They all died between one and 14 days after splenectomy (mean survival $4 \pm 1$ days) with a mean plasma glucose before death of 312 $\pm 24 \mathrm{mg} / 100 \mathrm{ml}$. The remaining dogs in the experimental groups have remained normoglycaemic throughout 6 months of observation.

Spleen Morphology. Except for the one ruptured spleen and the one spleen with a cyst in the lower pole, all spleens examined at autopsy or at the time of splenectomy showed perisplenic adhesions, but were otherwise grossly normal. Pancreatic tissue, irregularly distributed throughout the splenic pulp, was easy to detect on light microscopic examination of sections stained with $\mathrm{H} \& \mathrm{E}$ (Fig. 4). The charac- 
Table 2. K-values from glucose tolerance tests in transplanted dogs compared to normal and apancreatic (APC) control dogs

\begin{tabular}{ll}
\hline Group (n) & $\begin{array}{l}\text { Mean } \pm \text { SEM } \\
\text { K-Value }\end{array}$ \\
\hline Normal (22) & $3.30 \pm 0.27$ \\
Apancreatic (6) & $0.35 \pm 0.5$ \\
$15^{\prime}$ transplanted (7) & $1.20 \pm 0.19$ \\
$20^{\prime}$ transplanted (7) & $1.60 \pm 0.25$ \\
$25^{\prime}$ transplanted (6) & $0.78 \pm 0.08$ \\
\hline
\end{tabular}

Significance of differences

between Groups: 25' vs. APC, $\mathrm{p}<0.001$

$$
\begin{aligned}
& 20^{\prime} \text { vs. } \mathrm{NC}, \mathrm{p}<0.005 \\
& 20^{\prime} \text { vs. } 25^{\prime}, \mathrm{p}<0.02 \\
& 20^{\prime} \text { vs. } 15^{\prime}, \mathrm{p}<0.3 \\
& 15^{\prime} \text { vs. } 25^{\prime}, \mathrm{p}<0.1
\end{aligned}
$$

Table 3. Total pancreatic tissue insulin and amylase content before and after mincing and collagenase digestion for varying lengths of time

\begin{tabular}{lclll}
\hline & $\begin{array}{l}\text { Insulin }^{\mathrm{a}} \\
\mu \mathrm{g} / \text { pancreas }\end{array}$ & $\begin{array}{l}\text { Percent } \\
\text { Recovery }\end{array}$ & $\begin{array}{l}\text { Amylase }^{\mathrm{a}} \\
\mathrm{mg} / \text { pancreas }\end{array}$ & $\begin{array}{l}\text { Percent } \\
\text { Remaining }\end{array}$ \\
\hline $\begin{array}{l}\text { Whole Pancreas } \\
(\mathrm{n}=33)\end{array}$ & $2253 \pm 296$ & 100 & $289 \pm 26$ & 100 \\
$\begin{array}{l}\text { After Mincing } \\
(\mathrm{n}=33)\end{array}$ & $1276 \pm 162$ & 56.6 & $114 \pm 11$ & 39.4 \\
After & & & & \\
Collagenase & & & & \\
Digestion & & & & \\
$0^{\prime}(\mathrm{n}=5)$ & $1380 \pm 353$ & 58.0 & $115 \pm 28$ & 39.9 \\
$10^{\prime}(\mathrm{n}=7)$ & $406 \pm 112$ & 18.0 & $23 \pm 7$ & 7.9 \\
$15^{\prime}(\mathrm{n}=8)$ & $241 \pm 72$ & 10.7 & $20 \pm 6$ & 6.9 \\
$20^{\prime}(\mathrm{n}=7)$ & $166 \pm 34$ & 7.4 & $18 \pm 6$ & 6.2 \\
$25^{\prime}(\mathrm{n}=6)$ & $123 \pm 46$ & 5.5 & $14 \pm 8$ & 4.7 \\
\hline
\end{tabular}

a Values expressed as Mean $\pm \mathrm{SEM}$

teristic morphologic configuration of the acinar tissue was unmistakable.

There was no abnormal reaction of the surrounding splenic tissue in the vicinity of the implanted pancreatic tissue. In some areas the pancreatic tissue was arranged in small cysts lined with flattened epithelial appearing cells. Other areas harboured well formed acini. Zymogen granules could be identified at the apex of pyramidal exocrine cells upon staining with PTAH (Fig. 5).

Using aldehyde fuchsin stain, beta cells were positively identified in the vicinity of exocrine tissue and elsewhere in the spleen. We detected solitary cells as well as structures resembling intact islets of Langerhans. Beta cells were partially degranulated, but under high power oil immersion lens aldehyde fuchsin positive material was demonstrated to consist of discrete intracellular granules.

\section{Insulin and Amylase Content of Pancreatic Tissue}

Pancreatic processing resulted in a loss of tissue insulin and amylase. The mean total pancreatic insulin and amylase contents before and after processing are summarized in Table 3 . Slightly less than half of total tissue insulin and more than half of tissue amylase were lost during mincing. Tissue insulin and amylase content decreased with increasing lengths of collagenase digestion, indicating destruction of both islets and exocrine tissue during the digestion process.

\section{Discussion}

Previous failures with transplantation of the adult pancreatic fragments [31] led to the concept that a pure pancreatic islet preparation was most desirable for successful transplantation [1, 2, 4, 5]. To achieve that goal, cumbersome methods (Ficoll gradient separation or hand picking under a dissecting microscope) were used to isolate islets from dispersed pancreas. Unfortunately, these techniques result in islet loss $[17,18]$, require multiple donors to obtain a sufficient quantity of islets for transplantation $[1,18]$, and are difficult to apply to a higher species $[15,16]$.

Our experiment and the results of other studies [22] show that in the dog diabetes can be ameliorated by transplantation of pancreatic fragments without separation of exocrine and endocrine components. The spleen can accommodate the large volume of tissue that must be tranplanted when islets are not isolated. The presence of exocrine tissue seems to have no detrimental effect on the transplanted islets.

Islet embolization to the liver by direct injection into the portal system increases the efficiency of islet transplantation in rats $[5,20]$, but is impractical for infusion of large quantities of fresh pancreatic fragments in the dog because of the induction of portal hypertension [21]. Transplantation to the spleen may provide physiological benefits similar to those ascribed to intrahepatic transplantation by assuring that insulin secreted by the grafted tissue drains into the portal system via the splenic vein. In addition, the spleen appears to be relatively resistant to damage by implanted pancreatic exocrine tissue. This resistance may be related to dilution of the exocrine enzymes by the rapid sinusoidal blood flow of the spleen, although no direct measurements were made in our experiments to support this hypothesis. A well vascularized bed favourably influences the results of endocrine tissue transplantation in general 
[31], and the spleen provides the transplanted tissue with ideal access to a blood supply.

From the technical point of view, transplanting pancreatic fragments into the spleen is feasible. Neither arterial nor venous blood supply was compromised by the direct puncture and haemostasis was easily achieved. Cross clamping the splenic vessels during tissue implantation effectively kept the tissue within the splenic pulp, as proven by the recurrence of hyperglycaemia and death after splenectomy in transplanted dogs. Mean survival after removal of the spleen was similar to that of control dogs after pancreatectomy.

Histologically, all pancreatic tissue components were identified in the spleens of recipient dogs. Islets stained positive with aldehyde fuchsin, although beta cells were not as heavily granulated as in normal pancreas. Acinar cells were easily identified and were packed with zymogen granules, perhaps owing to the lack of a stimulus for secretion. The presence of exocrine tissue within the spleen did not appear to be detrimental to associated islets or to surrounding splenic parenchyma. The one incident of a splenic cyst could not be definitely attributed to degeneration of exocrine tissue because the amylase level of the cyst fluid was equivalent to normal serum amylase levels.

The preparation of the pancreatic tissue for transplantation was particularly important. As in all free grafts, the size of the tissue fragments was critical. Mechanical mincing alone was not sufficient and tissue dispersal by collagenase digestion was needed. Although islet loss (as judged by tissue insulin content) occurred with mincing alone, collagenase digestion was responsible for the majority of islet tissue attrition. By avoiding collagenase digestion, the islet yields were higher, but the results of transplantation were poorest and normoglycaemia could not be achieved. Although collagenase digestion of the pancreatic tissue was necessary, a balance existed between the need for tissue dispersal and for preservation of islet mass. Digestion for 10 minutes was relatively ineffective. However, all but one dog receiving tissue digested for 15 minutes became normoglycaemic. Digestion for 20 minutes appeared to provide the optimal balance, even though the average islet yield was only 7.4 percent. All dogs transplanted with tissue digested for 20 minutes became normoglycaemic. Digestion for 25 minutes resulted in an average islet yield of 5.5 percent; although the dogs in this group had fasting normoglycaemia, glucose and tolbutamide tolerance curves were clearly inferior to the 20 minute group.

Our experiments show that islets within appropriately dispersed pancreatic fragments are able to maintain normal fasting plasma glucose levels when transplanted to the spleen of totally pancreatectomized dogs. Recipient animals are also able to respond functionally to challenge with glucose and tolbutamide. However, even in the best experimental group (20 minutes digestion), elimination of glucose from the circulation was not as efficient as in normal animals (as determined by $\mathrm{K}$ value). Furthermore, insulin concentration in the peripheral circulation did not increase following glucose or tolbutamide stimulation. Similar observations have been made in rats following islet transplantation. Most likely insulin secretion is less than in normal animals, and insulin levels do not increase in the peripheral blood, because of almost complete hepatic extraction. Measurement of splenic vein insulin concentration in future experiments will be necessary to verify this hypothesis.

Since total pancreatectomy provides an absolutely lethal diabetes when untreated, the results of transplantation are satisfactory. However, conservation of more islets during the pancreatic fragment preparation procedure, while maintaining the same degree of tissue dispersal, is required if carbohydrate metabolism is to be improved further in transplanted animals.

The ultimate application of this technique to clinical diabetes appears promising. The recent success by surgeons in repairing or conservatively treating splenic injury $[32,33]$ suggests that the human spleen will be able to withstand the assault of tissue implantation. The response of the spleen to allogeneic tissue may be quite different from the response to autogenous tissue. Further experiments using pancreatic tissue allografts are needed in canine and other models of experimental diabetes.

Acknowledgements. This work was supported by USPHS grant AM16566, and by grants from the American Diabetes Association, Minnesota Chapter and the Juvenile Diabetes Foundation. Dr. Kretschmer is the recipient of a research scholarship from the Max Kade Foundation, Inc., New York. Dr. Sutherland is the recipient of USPHS Research Career Development Award 1 K04 AM00161.

We are grateful to Thomas L. Cain, Les Olson, Ann Lowe, Elizabeth Frenzel, Phyllis Gorecki and June Eckhardt for their technical assistance and to Janet Sanders for her help in the preparation of this manuscript.

\section{References}

1. Ballinger, W.F., Lacy, P.E.: Transplantation of intact pancreatic islets in rats. Surgery 72, 175-186 (1972)

2. Gates, R. J., Hunt, M. I., Smith, R., Lazarus, N. R.: Return to normal of blood-glucose, plasma insulin, and weight gain in New Zealand obese mice after implantation of islets of Langerhans. Lancet 1972 II, 567-570 
3. Leonard, R.J., Lazarow, A., Hegre, O.D.: Pancreatic islet transplantation in the rat. Diabetes 22 (Suppl.), 413-428 (1973)

4. Reckard, C.R., Ziegler, M. M., Barker, C.F.: Physiological and immunological consequences of transplanting isolated pancreatic islets. Surgery 74, 91-99 (1973)

5. Kemp, C. B., Knight, M. J., Scharp, D. W., Ballinger, W.F., Lacy, P.E.: Effect of transplantation site on the results of pancreatic islet isografts in diabetic rats. Diabetologia 9, 486-491 (1973)

6. Steffes, M.W., Sutherland, D. E. R., Mauer, S. M., Leonard, R. J., Najarian, J.S., Brown, D.M.: Plasma insulin and glucose levels in diabetic rats prior to and following islet transplantation. J. Lab. Clin. Med. 85, 75-81 (1975)

7. Brown, J., Molnar, I. G., Clark, W., Mullen, Y.: Control of experimental diabetes mellitus in rats by transplantation of fetal pancreas. Science 184, 1377-1379 (1974)

8. Slijepcevic, M., Helmke, K., Federlin, K.: Islet transplantation in experimental diabetes of the rat. I. Comparative studies: Pancreatectomy - streptozotocin. Horm. Metab. Res. 7, 20-25 (1975)

9. Reckard, C.R., Barker, C. F.: Transplantation of isolated pancreatic islets across strong and weak histocompatibility barriers. Transplant. Proc. 5, 761-763 (1973)

10. Panijayanond, P., Monaco, A. P.: Enhancement of pancreatic islet allograft survival with ALS and donor bone marrow. Surg. Forum 25, 379-381 (1974)

11. Naji, A., Reckard, C.R., Ziegler, M.M., Barker, C. F.: Vulnerability of pancreatic islets to immune cells and serum. Surg. Forum 26, 459-461 (1975)

12. Marquet, R.L., Heyster, G.A.: The effect of immunosuppressive treatment on the survival of allogeneic islets of Langerhans in rats. Transplantation 20, 428-431 (1975)

13. Slijepcevic, M., Helmke, K., Federlin, K.: Islet transplantation in experimental diabetes in the rat. III. Studies in allogeneic streptozotocin-treated rats. Horm. Metab. Res. 7, 456-461 (1975)

14. Nelken, D., Morse, S. I., Beyer, M. M., Friedman, E. A.: Prolonged survival of allotransplanted islet of Langerhans cells in the rat. Transplantation 22, 74-75 (1976)

15. Sutherland, D. E.R., Steffes, M. W., Bauer, G. E., McManus, D., Noe, B.D., Najarian, J.S.: Isolation of human and porcine islets of Langerhans and islet transplantation in pigs. J. Surg. Res. 16, 102-111 (1974)

16. Scharp, D. W., Murphy, J. J., Newton, W.T., Ballinger, W. F., Lacy, P. E.: Transplantation of islets of Langerhans in diabetic rhesus monkeys. Surgery 77, 100-105 (1975)

17. Lacy, P.E., Kostianovsky, M.: Method for the isolation of intact islets of Langerhans from the rat pancreas. Diabetes 16, 35-39 (1967)

18. Matas, A.J., Sutherland, D.E.R., Najarian, J. S.: Current status of islet and pancreas transplantation in diabetes. Diabetes $25,785-795$ (1976)
19. Leonard, R.J., Lazarow, A., McEvoy, R. C., Hegre, O.D.: Islet cell transplantation. Kidney Int. 6 (Suppl. 1), 169-178 (1974)

20. Matas, A. J., Sutherland, D.E.R., Steffes, M. W., Najarian, J.S.: Islet transplantation using neonatal rat pancreata: Quantitative studies. J. Surg. Res. 20, 143-147 (1976)

21. Matas, A.J., Sutherland, D.E.R., Steffes, M.W., Najarian, J.S.: Short-term culture of adult pancreatic fragments for purification and transplantation of islets of Langerhans. Surgery 80, 183-191 (1976)

22. Mirkovitch, V., Campiche, M.: Successful intrasplenic autotransplantation of pancreatic tissue in totally pancreatectomized dogs. Transplantation 21, 265-269 (1976)

23. Sutherland, D.E.R., Matas, A.J., Steffes, M.W., Najarian, J.S.: Infant human pancreas: A potential source of islet tissue for transplantation. Diabetes 25, 1123-1128 (1976)

24. Morgan, C.R., Lazarow, A.: Immunoassay of insulin: Two antibody system. Plasma insulin levels of normal, subdiabetic and diabetic rats. Diabetes 12, 115-126 (1963)

25. Jamieson, A.D., Pruitt, K.M., Caldwell, R. C.: An improved amylase assay. J. Dent. Res. 48, 483 (1969)

26. Kadish, A. H., Litle, R.L., Sternberg, J. C.: A new and rapid method for the determination of glucose by measurement of rate of oxygen consumption. Clin. Chem. 114, 116-131 (1968)

27. Moorhouse, J. A., Grahame, G. R., Rosen, N. J.: Relationship between intravenous glucose tolerance and fasting blood glucose level in healthy and in diabetic subjects. J. Clin. Endocrinol. 24, 145-159 (1964)

28. Lillie, R. D.: Histopathologic Technic and Practical Histochemistry, 3rd edition, p. 537-538. New York: McGraw-Hill Book Company, Inc. 1965

29. Lieb, E.: Modified phosphotungstic acid-hematoxylin stain. Arch. Pathol. 45, 559-560 (1948)

30. Gomori, G.: Aldehyde-fuchsin, a new stain for elastic tissue. Am. J. Clin. Pathol. 20, 665-666 (1950)

31. Brooks, J. R.: Endocrine Tissue Transplantation, pp. 83-85. Springfield: Charles Thomas 1962

32. Morgenstern, L.: Microcrystalline collagen used in experimental splenic injury: A new surface hemostatic agent. Arch. Surg. 109, 44-47 (1974)

33. Febri, P.J., Metz, E.N., Nick, W.V., Zollinger, R.M.: A quarter century with splenectomy: Changing concepts. Arch. Surg. 108, 569-575 (1974)

Received: February 3, 1977, and in revised form: May 10, 1977

D. E. R. Sutherland, M. D

Box 253

Mayo Memorial Building

University of Minnesota Hospitals

Minneapolis, MN 55455

USA 